\title{
Development and Characterization of Optical Dissolved Oxygen Sensor based on the Fluorescence Detection
}

\author{
Hyun Min KWAK ${ }^{1}$, Myeunghoi $\mathrm{KWON}^{1^{*}}$ and Gyewoon $\mathrm{CHOI}^{1}$ \\ Yoonseok JUNG ${ }^{2}$, Changhwan JUNG ${ }^{2}$, Kiuha PARK ${ }^{2}$, Okjae SOHN ${ }^{2}$ \\ and Junhyong $\mathrm{KIM}^{2}$ \\ ${ }^{1}$ Physics Department Incheon National University, \\ ${ }^{2}$ Global Optical Communication Co., Ltd. \\ 형광검출기반 광학식 용존산소 측정센서 개발 및 특성 분석 \\ 곽현민 $^{1}$, 권명회 $^{1^{*}}$, 최계운 ${ }^{1}$, 정윤석 ${ }^{2}$, 정창환 $^{2}$, 박규하 $^{2}$, 손옥재 $^{2}$, 김준형 ${ }^{2}$ \\ ${ }^{1}$ 인천대학교 물리학과, ${ }^{2}$ 글로벌 광통신주식회사
}

\begin{abstract}
We developed and evaluated a fluorescence-based optical DO sensor (OS-100, Global Optical Communication Ltd., Korea) for long-term monitoring of the dissolved oxygen concentration in waste water treatment. Fluorescent sensing membrane containing $\mathrm{Ru}(\mathrm{Dpp})_{3}{ }^{2+}$ (tris(4,7diphenyl-1, 10-phenanthroline) ruthenium(II)) was prepared with GA sol-gel matrix and coated on a quartz plate by sprayed method. Properties of sensor film exhibit deviation about $\pm 1 \%$ under wide range of DO concentration from 3 to 10 . The developed optical DO sensor was actually mounted in waste water from dyeing industry and successfully applied for on-line DO monitoring. Online monitoring results showed the changes of DO concentrations in wastewater treatment processes with accuracy better than $\pm 2 \%$ during the 6 months measurements period in vicious environmental conditions.

요 약 오폐수 처리에 있어서 용존산소량을 장기간, 연속측정이 가능한 DO 센서의 개발이 요구되어, 형광검출 특성을 이용한 광학식 DO 센서를 개발하고 특성을 분석하였다 (OS-100, 글로벌광통신주식회사). 형광 센서막은 $\mathrm{GA}$ 를 이용하여 졸-겔 방법을 이용하여 $\mathrm{Ru}(\mathrm{Dpp})_{3}{ }^{2+}$ (tris(4,7diphenyl-1, 10-phenanthroline) ruthenium(II)) 형광물질을 제작하였고, 용액과 혼 합하여 스프레이 방법으로 석영기판위에 증착하였다. 증착된 형광막은 용존산소 농도 $3 \mathrm{mg} / \mathrm{L}$ 에서 $10 \mathrm{mg} / \mathrm{L} \mathrm{사이의} \mathrm{넓은}$ 영역에서 $\pm 1 \%$ 이하의 오차를 보였다. 제작된 광학식 DO 센서의 성능평가를 위하여 대구염색단지의 오폐수처리장 폐수 의 실시간 용존산소를 장기간 측정하였다. 6 개월간의 장기간에 걸쳐 실시간 측정된 용존산소의 결과는 염색공단 폐수의 악조건 하에서도 $\pm 2 \%$ 이하의 오차를 나타내었다.
\end{abstract}

Key Words : Dissolved; oxygen, Fluorescence detection, On-line monitoring, Optical sensor

\section{Introduction}

Monitoring and controlling of dissolved oxygen (DO) concentration in water treatment is the most important parameter for determining the effectiveness and quality of water treatment. [1] Among the developed DO sensors, such as titration sensor, amperometric sensor, chemi-luminescence sensor, and thermo-luminescence

This research was supported by a grant (12-TI-C01) from Advanced Water Management Research Program funded by Ministry of Land, Infrastructure and Transport of Korean government.

*Corresponding Author: Myeunghoi KWON(Incheon National Univ.)

Tel: +82-11-9049-8223 email: kwonmh@incheon.ac.kr

Received December 17, 2013 Revised January 8, 2014 Accepted January 9, 2014 
sensor, amperometers based on the Clark electrodes are widely used in the biological, environmental, and industrial areas due to their ideal response to oxygen concentration in solution. [2,3] However, these electrode type sensors have several drawbacks such as sluggish response, difficult to miniaturize, electromagnetic interferences with other sensors, etc. Over the past decades, the development and applications of optical sensors have grown rapidly because of their fast response, good sensitivity and selectivity, and long-term stability. Optical DO sensors are based on oxygen dependent changes of the luminescence of certain indicator molecules in certain solid substrates. However, the leaching of the indicators, the substrates and the linking bonds between the indicators and substrates are serious problems for operating sensors in vicious condition.

We developed optical DO sensor using optical fiber method with oxygen sensitive fluorophore $\left[R u(d p p)_{3}\right]^{2+}$ film. Oxygen sensor xerogels were prepared using the mixture of organosilicone precursor and solution of $\left[\mathrm{Ru}(\mathrm{dpp})_{3}\right]^{2+}$. Oxygen existence in solution quench the excited-state lifetime of the luminophore $\left[R u(d p p)_{3}\right]^{2+}$. $[4,5]$ The quenching process is described by the Stern-Volmer equation.

$$
\frac{I_{0}}{I}=\frac{\tau_{0}}{\tau}=1+K_{S V}\left[p O_{2}\right]=1+k_{q} \tau_{0}\left[p O_{2}\right]
$$

Where $I_{0}$ and $\tau_{0}$ are the fluorescence intensity and decay time of the luminophore in the absence of oxygen, respectively. $\mathrm{K}_{\mathrm{SV}}$ is the sensor sensitivity by Stern-Volmer constant, $\mathrm{pO}_{2}$ is the partial pressure of oxygen, and $\mathrm{k}_{\mathrm{Q}}$ is the quenching constant, which incorporates the oxygen diffusion coefficient for the matrix.

Oxygen sensitive sensor film was prepared by sprayed coating of oxygen sensitive xerogel on the quartz plate. Covalent immobilization of $\mathrm{Ru}(\mathrm{dpp})_{3}$ in the sol-gel matrix was accomplished by the reaction of the $\mathrm{Ru}(\mathrm{dpp})_{3}$ linked sol-gel precursor with atetraethyorthosilicated (TEOS) under acid conditions. The developed DO sensor equipped with a blue LED for excitation of luminescent sensor film and silicon photodiode for the detection of the oxygen sensitive luminescent signal. In this paper, we report on the result of measurement of dissolved oxygen in factory wastes under vicious environmental condition during the 6 months period without calibration. Optical
DO sensor with $\left[\mathrm{Ru}(\mathrm{dpp})_{3}\right]^{2+}$ doped xerogels film reported here is suitable for industrial and environmental applications such as service water, sewage, wastewater, and seawater, where the key sensor characteristics are :enhanced oxygen sensitivity and insensitivity to hydrogen presence, long-term stability, and fast response.

\section{Discussion}

\subsection{Experimental}

The covalent immobilization of dissolved oxygen sensitive luminophore tris(4,7diphenyl-1,10-phenanthroline) ruthenium(II) complex $\mathrm{Ru}(\mathrm{Dpp})_{3}{ }^{2+}$ in the sol-gel matrix was accomplished with a sol-gel solution containing tetraethyorthosilicated (TEOS) under acidic conditions. The sensing membrane was obtained by spraying method with homemade spray device onto a quartz glass of $9 \mathrm{~mm}$ diameter and $1 \mathrm{~mm}$ thickness. For uniform and firm coating, GPTMS (3-glycidoxypropyl trimethoxy silane) and APTMS (3-aminopropyl triethoxy silane) were dissolved in 99\% purity ethanol and adding 35\% $\mathrm{HCl}$. [6] Prepared mixture with G:A:Et-OH:DW:HCl $=1.25$ mL:625 $\mu \mathrm{L}: 2.708 \mathrm{~mL}: 5.417 \mathrm{~mL}: 400 \mu \mathrm{L}$ was left under stirring at room temperature for $3 \mathrm{hrs}$ for forming GA sol-gel. [7] Then oxygen indicator luminophore was added into the mixture and was sprayed onto the quartz glass The sprayed homogeneous indicator-doped mixture on the quartz was dried $24 \mathrm{hrs}$ and finally heated at $60{ }^{\circ} \mathrm{C}$ for $48 \mathrm{hrs}$. Fluorescence intensity of $590 \mathrm{~nm}$ of the synthesized membrane did not change during the test period of 6 months in distilled water. These results demonstrate no dye leaching from the membrane by their covalent immobilization in gel. Fig. 1.a shows the 2D fluorescence spectra of the covalently immobilized sensing membrane. This membrane exhibits a strong fluorescence emission at $590 \mathrm{~nm}$ when excited by $470 \mathrm{~nm}$ radiation in aqueous media deaerated by bubbling N2 gas. Fluorescence emission intensity was reduced by the quenching process of dissolved oxygen in liquid as shown in Fig. 1.b. 

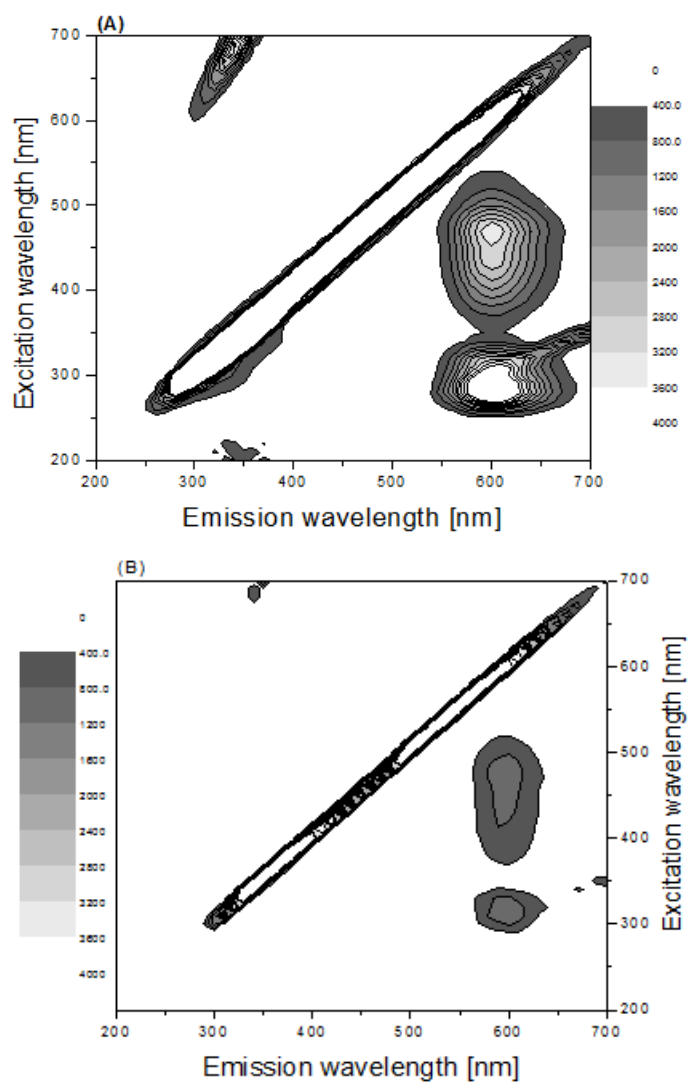

[Fig. 1] 2D-fluorescence spectra of optical sensing membrane, (A) $0 \%$ dissolved oxygen, (B) $100 \%$ dissolved oxygen.

Fig. 2 shows the instrumental setup realized to interrogate the sensing probe. Sensing probe at the tip of the optical fiber is illuminated by $470 \mathrm{~nm}$ blue light and luminescence $590 \mathrm{~nm}$ reflected beam is collected. It consists of a $470 \mathrm{~nm}$ high brightness LED (LB520, Seoul Semiconductor Co., Ltd., Korea), $2 \mathrm{~mm}$ dual branch plastic optical fiber (SH-8001, Mitsubishi Co., Japan), and silicon photodiode (OPT301M, Texas Instruments Co., USA). In this optical system, we adopted condensing lens and $600 \mathrm{~nm}$ bandpass filter for minimize the interference by the external light and for amplifying the low intensity of luminescence beam by the effect of dissolved oxygen. Generated electric signal is modulated by typical optoelectronic circuit as shown in Fig. 2 b.

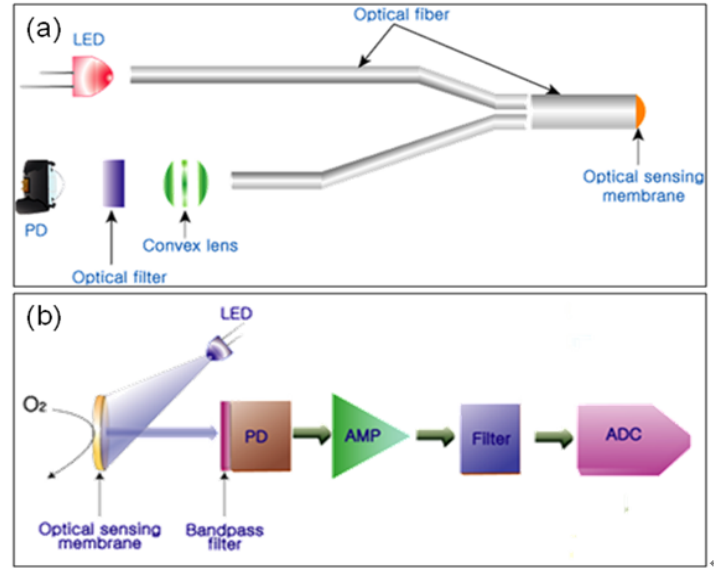

[Fig. 2] (A) Set-up of optical components and (B) optoelectronics

\subsection{Results and Discussion}

Typically, experimental results on the luminescent properties of oxygen sensitive luminophores based on the ruthenium, iridium and palladium complexes have shown an excited state lifetime dependence on the temperature. [8] Fig. 3 shows the decreasing output signals of fluorescence intensities depend on the temperature at different amount of dissolved oxygen in water. Based on this observation, we used following equation for compensation. In this experiment, we used the method of KS I ISO 5813 (Winkler-Azide modification) for finding compensation values.

$$
\frac{\left(T-T_{L}\right) O_{2 H}+\left(T_{H}-T\right) O_{2 L}}{T_{H}-T_{L}}=O_{2}
$$

Where $\mathrm{T}$ is the measured temperature of solution by temperature sensor, $\mathrm{T}_{\mathrm{H}}$ and $\mathrm{T}_{\mathrm{L}}$ are the high and low values of compensation range of temperature. And $\mathrm{O}_{2 \mathrm{H}}$ and $\mathrm{O}_{2 \mathrm{~L}}$ are concentrations of dissolved oxygen at those temperature ranges. In our measurement system, we used the compensation coefficient by $5^{\circ} \mathrm{C}$ between the ranges of water temperature from $5{ }^{\circ} \mathrm{C}$ to $50^{\circ} \mathrm{C}$.

For characterizing our device in actual situation, we did comparative test between an amperometric sensor (YSI-550A, YSI Co., USA), often considered the reference for online oxygen measurement, and OS-100 sensor (Global Optical Communications Co., LTD., Korea) in different conditions. Fig. 4 illustrates comparative test results in phosphate buffer solution with 
$\mathrm{pH} 3$ to $\mathrm{pH} 10$. In this experiment, the OS-100 optical sensor is shown to measure with a less than $1 \%$ measurement error under the external ionic strength from $25 \mathrm{mM}$ to $200 \mathrm{mM}$. Also, it shows that the developed DO sensor does not influence by the presence of hydrogen ion. Fig. 5 shows 6 months period experimental data of DO concentration at wastewater treatment plant at Daegu Dyeing Industrial Center. The wastewater from dyeing industry has deteriorated condition such as high temperature, contains high alkaline substances compare to the typical wastewater or sea water. In this case, the OS-100 optical sensor is still shown to measure with $\pm 2 \%$ measurement error.

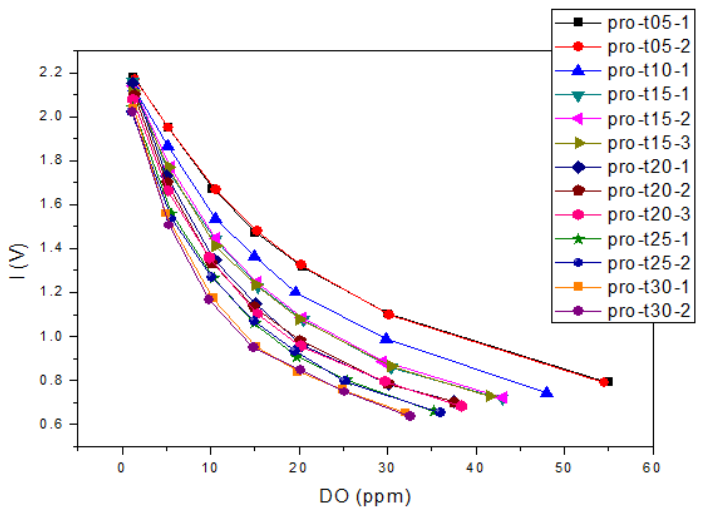

[Fig. 3] Effect of water temperature on the measurement of dissolved oxygen concentrations based on the ruthenium(II)-complex

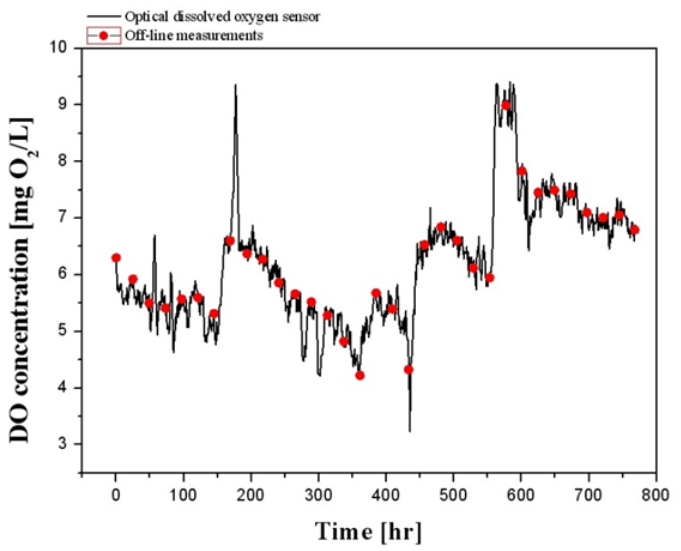

[Fig. 4] Long-term on-line measurements of DO concentrations with OS-100 sensor and comparison with off-line measurements

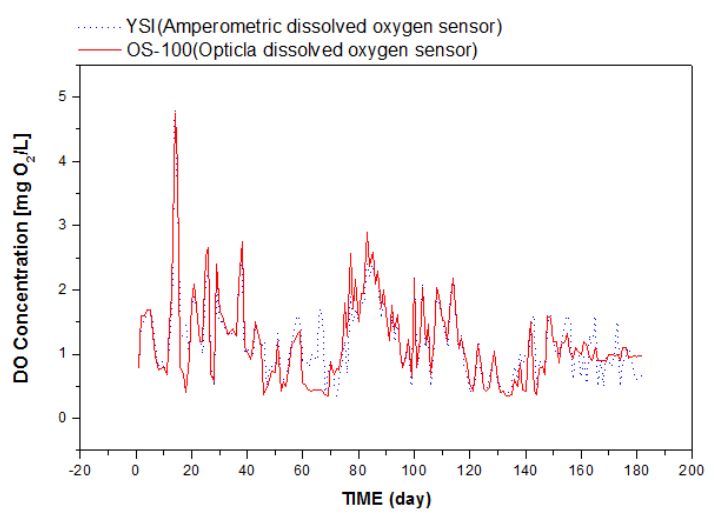

[Fig. 5] Comparative test of an OS-100 and YSI-550A in wastewater treatment plant (Daegu Dyeing Industrial Center, Korea)

\section{Conclusion}

We developed a fluorescence-based optical DO sensor for on-line monitoring of dissolved oxygen in wastewater. Oxygen sensitive sensor matrix was prepared using the mixture of organosilicon precursor and solution of $\left[\mathrm{Ru}(\mathrm{dpp})_{3}\right]^{2+}$ and was sprayed on quartz plate. Properties of sensor film exhibit deviation less than $\pm 1 \%$ under the wide range of DO concentration from 3 to 10 with temperature range of $4{ }^{\circ} \mathrm{C}$ and $50^{\circ} \mathrm{C}$. The developed optical DO sensor was actually mounted in wastewater at wastewater treatment plant on dyeing industry. We did online monitoring of DO concentration for 6 months in this vicious environmental condition. Experimental results showed the changes of DO concentrations in wastewater treatment processes with accuracy better than $\pm 2 \%$ during the 6 months measurements period. This sensor exhibits advantages over many existing optical DO sensors including wider dynamic DO concentration range, ease of fabrication and long-term stability in vicious condition. The application of this sensor for DO concentration monitoring of industrial processes is in progress in our laboratory.

\section{References}

[1] Sohn O.J. (2009), Microplate-based bioreactor equipped with an optical online monitoring system, 2009. Ph.D 
Thesis, Chonnam National University.

[2] Samantha M.G., Lukas C., Karen C.C. (2010), Optical oxygen sensors for applications in microfluidic cell culture, 2010. Sensors, pp.9286-9316.

[3] Stephen B., Frank D. (2012). A comparison of amperometric and optical dissolved oxygen sensors in power and industrial water applications at low oxygen levels. http://www.hach.com/asset-get.download.jsa?id=763998481 5.html.

[4] Bergman I. (1968), Rapid-response atmospheric oxygen monitor based on fluorescence quenching, 1968. Nature, pp.396.

DOI: http://dx.doi.org/10.1038/218396a0

[5] 5. Wilson D.F., Vinogradov S.A. (2003). Tissue oxygen measurements using phosphorescence quenching. In Handbook of Biomedical Fluorescence; Mycek, M.A., Pogue, B.W. Eds.; Marcel Dekker: NewYork, NY, USA, 2003, pp.637-662.

[6] Stitt D.T., Nagar M.S., Haq T.A., Timmins M.R. (2002), Determination of growth rate of microorganism in broth from oxygen-sensitive fluorescence plate reader measurements, 2002. Bio-Techniques, pp.684-689.

[7] Kim S.Y., Kim C.K., Sohn O.J., Rhee J.I. (2009), Monitoring of $\mathrm{pH}$ and dissolved oxygen in microorganism fermentation processes using 24-well microplate. KSBB Journal, pp.207-211.

[8] William R.C. (2005), Temperature and solventdependent luminescent properties of tris (2,2-bipyridyl) ruthenium(II) chloride, Senior honors thesis, Eastern Michigan University

\section{Hyun Min Kwak}

[Associate member]

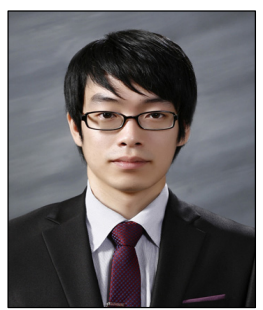

- Feb. 2012 : Incheon National University, Physics Department (BA)

- Feb. 2014 : Incheon National University, Physics Department (MS)

$<$ Research Interests $>$

CIGS solar cell, Thin film semiconductor
Myeung Hoi Kwon

[Regular member]

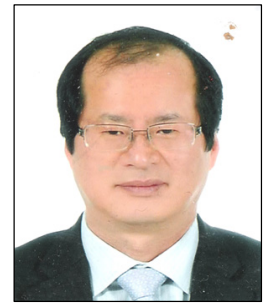

- Dec. 1990 : Texas Tech University, Physics Department (Ph.D)

- Mar. $1991 \sim$ current : Incheon National University, Physics Department (Professor)

$<$ Research Interests $>$

Nano material synthesis, Applied Physics

\section{Gyewoon Choi}

[Regular member]

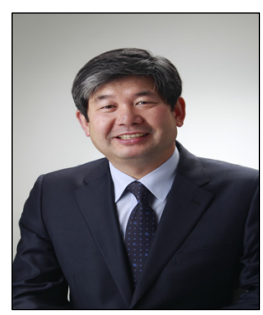

- Dec. 1991 : Colorado State University (Enginneing Doctor)

- Jul. $1994 \sim$ current : Incheon National University, Civil Engineering (Professor)

$<$ Research Interests $>$

Hydrodynamics, Water and sewege

\section{Yoon-Seok Jung}

[Regular member]

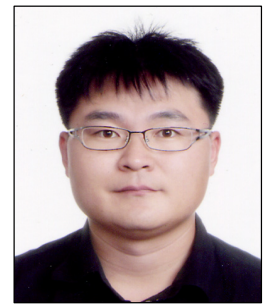

- Feb. 2007 : Chosun University, Polymer Engineering (ME)

- Jan. $2007 \sim$ current : Global Optical Communication(Ltd) Senior Researcher

$<$ Research Interests $>$

Polymer Materials, Optical Cable and Optical Sensor 
Chang-Hwan Jung

[Regular member]

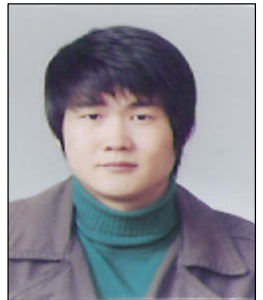

- Feb. 2011 : Cheonnam National University, New Materials Engineering (ME)

- Apr. 2012. current : Global Optical Communication(Ltd) Researcher

$<$ Research Interests $>$

Chemical Engineering, Liquid Sensor

\section{Kiu-Ha Park}

[Regular member]

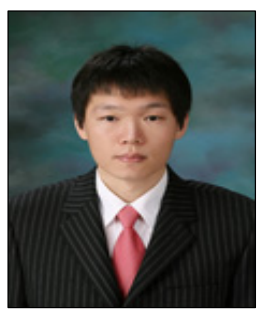

- Feb. 2009 : Honam University Electrical Engiuneering (ME)

- Dec. $2008 \sim$ current : Global Optical Communication(Ltd) Researcher

$<$ Research Interests $>$

Optics, Liquid Sensor and application

\section{Ok-Jae Sohn}

[Regular member]

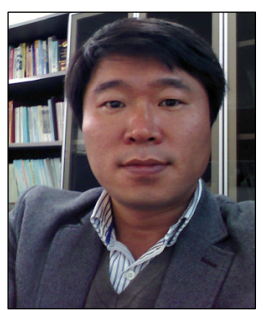

- Feb. 2009 : Cheonnam National University, New Materials-Biology Engineering (Engineering Doctor)

- Jul. $2013 \sim$ current : Global Optical Communication(Ltd) Representive Researcher
Jun-Hyong Kim

[Regular member]

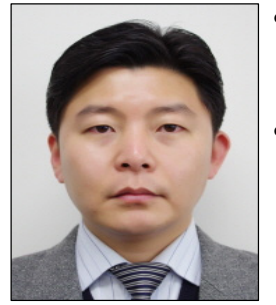

- Feb. 2009 : Cheonnam National University, Optical Engineering (Engineering Doctor)

- Mar. $2009 \sim$ current : Global Optical Communication(Ltd), President in Research Institute

$<$ Research Interests $>$

Optical Sensor, Optical Device, Monitoring System

$<$ Research Interests $>$

Environment Monitoring, Optical Sensor 